\title{
CORRELATION BETWEEN MARKETING STRATEGY, PRODUCT QUALITY AND PROMOTION ON THE MOBILE DEVICES MARKET IN SERBIA
}

\author{
Mihalj BAKATOR ${ }^{1}$, Nikola PETROVIĆ ${ }^{2}$ \\ ${ }^{1}$ Republic of Serbia \\ E-mail: mihaljbakator@gmail.com \\ ${ }^{2}$ Republic of Serbia \\ Paper received: 01.11.2016.; Paper accepted: 14.11.2016.
}

\begin{abstract}
This paper examines the correlation between promotion as a marketing mix instrument, product quality and marketing strategy on the mobile devices market. The research paper consists of four sections. Each section determines the key factors of the main subject's elements. The research makes analysis of the influence of promotional activities on consumer behavior. It was conducted via survey questions. The questions referred to mobile device brands, user satisfactory rates and other parameters in the Republic of Serbia. The aim was to define the impact of promotional activities on consumer choice when purchasing a mobile device. In addition, the product quality and marketing strategies of top mobile device brands are also taken into consideration. Observational statements are made based on statistical evidence from the completed research surveys.
\end{abstract}

Keywords: Correlation, Promotion, Product quality, Marketing strategy, Mobile device.

\section{INTRODUCTION}

The mobile devices market is very dynamic. A large number of manufacturers compete with each other. Their aim is to secure a solid piece of the market "cake". With over a hundred brands of mobile devices, it takes much effort to stand out from the competition. Strong marketing strategies make it feasible to accomplish advantageous market positions. Generally, it is accepted that strong brands achieve better market positions (Keller, 2001). However, innovation is one of the most important tools for ranking up on various markets (Johnston and Marshall, 2016). This applies even more strongly to electronic devices markets. On these markets innovation is the main component of good business performance.

In Serbia there are strong mobile device brands that overwhelm the competition. Samsung, Apple, Microsoft Mobile and LG are the most popular mobile device manufacturers (Huang et al., 2016). This is presumably due to aggressive promotion and effective marketing strategy. Promotion of the top mobile device manufacturers needs less effort to achieve the goal when it comes to consumers.

The goal is to influence people into buying mobile devices from specific manufacturers or brands (Shankar and Balasubramanian, 2009). Promotional activities aim for inventory reduction or financial plan achievement before a defined deadline. Companies compete on the market with the aim of binding the customers to themselves. Binding is done through sales promotion activities. These activities increase product sales in a defined period when the promotion takes place (Alavuk et al., 2015).

Besides promotion and marketing strategy an insight will be given on product quality. The importance of product quality emerges from the main purpose of quality. Product quality represents the foundation for achieving business excellence and exceptional performance

The research in this paper taps into the effects of promotion and marketing strategy on consumer 
behavior. The aim of this study is to determine the correlation between product quality, marketing strategy and promotion on the mobile device market. The research included surveying of more than hundred mobile device users. The goal was to analyze the extent of aggressive promotion and its effects on consumers.

This paper is organized as follows: The first section gives an overview of marketing strategies that are used by leading mobile device manufacturers. The second section analyses the key concepts of product quality in a brief manner. The third section involves promotion and its effect on consumer behavior. The fourth section shows the results of the research. This includes figures and tables. Based on the research results, a discussion examines the correlation between marketing strategy, promotion and product quality on the mobile devices market in the Republic of Serbia. The paper as a whole approaches promotion as a marketing mix instrument that influences consumers. The impact of promotion influence is also measured. Measurement is based on product quality, marketing strategy, promotion and consumer satisfaction. In the literature there are many examples of promotional activities, and their influence on consumers.

\section{MARKETING STRATEGIES OF THE MAIN MOBILE DEVICE MANUFACTURERS}

\section{Marketing strategy}

The main mobile device manufacturers will be examined in the first section of this paper. The dominant mobile device manufacturers in Serbia are Apple Inc., Samsung, Microsoft Mobile and Huawei (Bakator, 2016). The other brands are just present on the market but they are not popular in that merit.

Marketing has a role in business development. This role is to research, define and examine market characteristics and factors. Marketing includes the market conditions and requests. Taking into consideration the requests, the marketing concept tries to answer them with product and service innovation (Đorđević and Ćoćkalo, 2010). Marketing strategies are based on long-term strategic goals. The pillars of marketing strategy are the four marketing mix instruments. Kotler et al. (2005) highlight the following marketing mix instruments:

- product
- price

- distribution

- promotion

Marketing strategies of "giant" mobile device manufacturers are conceptualized in a specific way. These marketing strategies are based on factors that impede consumer's decision making thought processes (Turnbull et al., 2000). These authors also state that the consumer confusion exists. This confusion manifests itself on many markets, especially on tech markets. The mobile device market is one of the markets prone to confusion. Although, consumer confusion manifests itself, it does not have a harmful effect on the market.

Turnbull et al. (2000) further suggest that the manufacturers should create a strong image of the brand. Also, manufacturers must consider the effects of consumer-to-consumer relationships. These relationships have a potentially high impact on the brand's image. Fjeldstad et al. (2004) suggest that strategic actions are crucial for good company and business performance. Strategic actions include long-term, customer oriented processes. These processes coherently influence each other and consumer behavior as well. Due to the sheer volume of promotional activities many false pictures are created from the consumer perspective. Branding as a concept plays a key role in the company's business development. Creating a strong brand is part of the company's urge to survive in a dynamic environment (Keller, 2001). Fast paced advancement in technology creates an unstable market. Unstable markets are full of risks for the market participants.

Further in this section, marketing strategies of the four most popular mobile device manufacturers will be analyzed.

\section{Samsung Electronics Company}

Samsung Electronics is the leader on the mobile devices market. The company manufactures more than fifty models of mobile devices. Samsung also produces a wide assortment of house appliances, personal computers and networking equipment. The company's pricing policy is based on brand popularity. Samsung aims at almost every segment of the mobile devices market. Through various distribution channels, the company measures its presence on the market. Some of the main 
promotional activities that Samsung practices are

the following (Shareef et al., 2016):

- advertising on television and social media platforms;

- presentations;

- sale coupons, prize games, demonstrations, specific ads;

- direct marketing;

- magazines, cinema and location media marketing.

Samsung dominates on the market and is the leading brand in Serbia (Schlegelmilch, 2016).

\section{Apple Company}

The Apple Company was founded in 1976. The company produces mobile phones, tablets, notebooks, music players and personal desktop computers. The Apple Company aims at consumers with higher purchasing power. The company uses the following promotional activities (Schlegelmilch, 2016):

- advertising on radio, television and internet;

- personal sales through presentation;

- publication, lobbing;

- direct marketing and catalog marketing.

The Apple Company is ranked second best mobile device manufacturer in Serbia.

\section{Huawei Company}

Another "giant" in the mobile devices market is the Chinese company Huawei. This multinational concern is specialized in telecommunications. The company was founded in 1987, and today Huawei has a strong brand on the mobile devices market. The company has over seventy models of high quality and high performance mobile devices. Beside these, Huawei manufactures networking hardware, telecommunication systems and amplifiers (Li Sun, 2009). Huawei produces high quality devices with respectable performance for a reasonable price. The broad product distribution channels ensure stable market coverage.

Some of the key promotional activities of Huawei are the following (Li Sun, 2009):

- advertising on television and social media;

- presentations;

- sales, specific ads;

- publications;

- integrated direct marketing;
- specialized technical journals.

\section{Microsoft Mobile Company}

The fourth strongest mobile device brand is Microsoft Mobile. The company was founded in 2014 when Microsoft purchased the Nokia Company's mobile phone division. In a relative short period of time, Microsoft Mobile introduced more than twenty new mobile device models. The company's aim is to spread the use of mobile devices that run Microsoft Windows operating systems. The company's distribution system allows great availability of mobile phones. Microsoft Mobile has a strong promotional strategy and this includes (Teixeira, 2015):

- advertising on television and social media;

- presentations;

- competitions, prize games, sales, specific ads, demonstrations, money back guarantees;

- publications, corporate communication;

- integrated marketing;

- journals, technical articles, and sponsorships.

\section{The importance of brands}

A good brand image makes a big difference on the market. The brand represents a name, symbol, shape or their combination with the goal to identify and differentiate products from one another (Keller et al., 2008). Berens et al. (2005) conducted a research on brand influence. Their findings showed that strong brands create an association with consumers. The brand significantly affects consumer decisions when it comes to buying a product (Keller et al., 2008). Based on the brief examination of top mobile device manufacturers and analysis of marketing strategy and brand from a theoretical view, the following is proposed:

Proposition 1: Structured and good marketing strategies are necessary for the creation of strong brands.

The main factors and concepts of mobile devices quality will be examined in the next section.

\section{PRODUCT QUALITY ON THE MOBILE DEVICES MARKET}

Product quality has the role to satisfy the consumers' needs. High quality products are more likely to become popular among potential consumers. There is a strong relation with product 
quality and consumer orientation. Consumers will probably buy products and services that guarantee high quality and reliability. Manufacturers with strong traditions in quality management have better chances for survival in a dynamic environment (Page, 2015).

Product quality ensures that customers will purchase again the same brand. A good quality product is more likely to attract new potential consumers. This is due to customer-to-customer relationships. Through these relationships information is distributed. The information, which is distributed, carries the positive or negative user experiences. Product quality represents a big part of the end-user experience when using a new product (Parker et al., 2015). The more positive is the experience the better is the message carried out through customer-to-customer relationships (Kotler and Keller, 2015). There is likely a strong connection between product quality and brand strength. Mobile devices require high technology manufacturing processes. It is not rare to see manufacturers lower the quality of raw materials in order to achieve higher profit margins. It is observed that there are big differences in build quality of similar mobile device models of the same brand (Yoon and Kim, 2015). The reason for this may lie in concept of market segment targeting.

Manufacturers want high percentage of sales for all the models. To achieve this, strategic product modifications have to be made. The modifications consist of downgrading components and build quality. The strong brand image can compensate this, because consumers are influenced by strong brand promotion and good experiences in the past (Khan and Ahmed, 2016). Based on the facts of brand and manufacturer manipulation with product quality the following is proposed:

Proposition 2: Manufacturers of mobile devices use the strong brand image to compensate the quality shortcomings of products and services.

According to Truong et al. (2016) brand name and brand popularity play an important role to a new product's success on the market. On high technology markets, there is a chance that popular brands compensate the lack of product quality, which further doesn't meet the consumers' expectations.

\section{THE ROLE OF PROMOTION ON THE MOBILE DEVICES MARKET}

Promotion, as one of the main marketing mix components, plays an important role in brand positioning. This is crucial due to constant changes that occur in various markets. In this paper the aim is to analyze and to connect consumer satisfaction, consumer behavior and the influence of promotion. Without a strong and effective promotion strategy companies are less likely to survive on a harsh market. Promotional activities are oriented on achieving different business objectives (Alavuk et al., 2015).

This especially refers to markets with high technological advancements and innovation. The mobile devices market is one of those innovation rich markets (Page, 2015). The impact of promotion on various consumer segments, and other promotion factors that determine the success of promotional activities is shown in Table 1.

Table 1: Factors that determine promotional activities

\begin{tabular}{|l|c|c|c|c|}
\hline $\begin{array}{l}\text { Factor/ } \\
\text { Promotional } \\
\text { activity }\end{array}$ & $\begin{array}{c}\text { Corporate } \\
\text { propaganda }\end{array}$ & Publicity & $\begin{array}{c}\text { Personal } \\
\text { sales }\end{array}$ & $\begin{array}{c}\text { Sales } \\
\text { improvement }\end{array}$ \\
\hline Auditorium & Massive & Massive & Low & Varies \\
\hline Message & Unique & Unique & Specific & Varies \\
\hline Cost & $\begin{array}{c}\text { Low per } \\
\text { spectator }\end{array}$ & $\begin{array}{c}\text { Not } \\
\text { present, } \\
\text { small for } \\
\text { dispersal }\end{array}$ & $\begin{array}{c}\text { High per } \\
\text { buyer }\end{array}$ & Small \\
\hline Sponsor & Company & none & Company & Company \\
\hline Flexibility & low & low & high & Low \\
\hline $\begin{array}{l}\text { Content and } \\
\text { placement } \\
\text { control }\end{array}$ & High & $\begin{array}{c}\text { None } \\
\text { existent }\end{array}$ & High & High \\
\hline Stringency & Low & High & Low & Low \\
\hline
\end{tabular}

Source: Đrođević and Ćoćkalo, 2010

Taking into consideration the amount of effort that goes into promotional activities and the number of factors, it can be assumed that promotion is important in developing a strong marketing strategy and a strong brand. The main goal of promotional activities is creating a good corporate image and a popular brand. A good corporate image is created by high quality products and services. Mobile device manufacturers advertise mostly on the Internet. This is done through social media marketing. This type of marketing brings good results for lower costs. Although, it is very popular, the enormous amount of advertisements can "burry" each other (Ashley and Tuten, 2015). Advertisement saturation is one the common disadvantages of promotional activities on the Internet. This is resolved with paid advertisements 
and advertisement rankings. The more financial resources are involved the higher the ranking of the advertisement. Higher rankings mean more views by potential customers (Schulze et al., 2015). Based on the observations of the conducted researches, the following propositions are stated:

Proposition 3: Promotional activities on social media are more likely to be effective through strategic marketing planning, and the lack of timely actions can result ad "burying", because of the high volume of advertising campaigns on social media sites.

\section{RESEARCH RESULTS}

The conducted research and its results are given in the form of figures. These figures are based on statistical data. Customer satisfaction with some of the mobile device manufacturer's brands are shown on Figure 1.

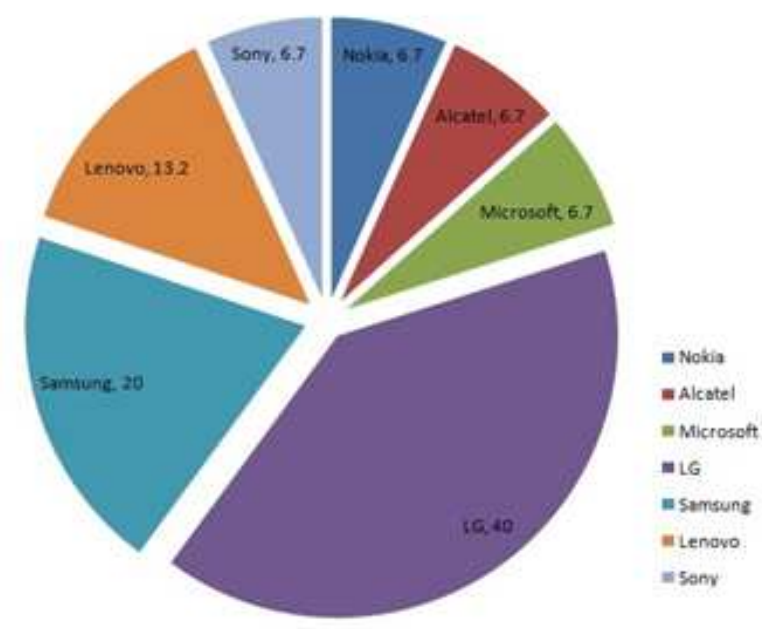

\section{Figure 1: Customer dissatisfaction with mobile} devices brands (percentage) (Bakator, 2016)

Figure 1 clearly shows that popular brands, such as LG, Samsung and others, have a high rate of unsatisfied users. Microsoft Mobile (including Nokia) has almost $15 \%$ unsatisfactory rate. The mobile devices that are manufactured by the Samsung Company create one fifth of the total dissatisfaction by the use of mobile devices of the mentioned brands. In the next section the role of promotion and the types of promotion will be analyzed. Furthermore, additional research results will be presented and examined.

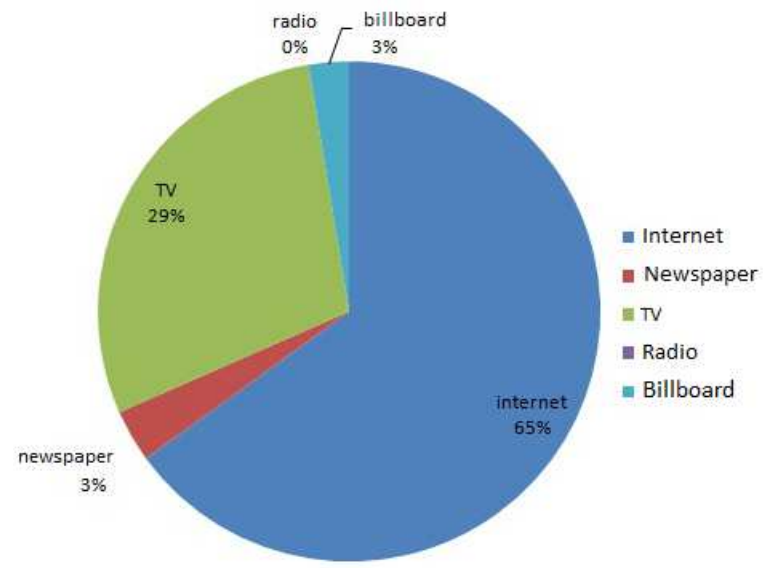

Figure 2: Consumers' subjective opinion (feeling) on the most frequent use of media for advertisements on the mobile devices market (Bakator, 2016)

The frequency of advertisements and media through which the ads are presented to the consumers are given in Figure 2.

Figure 2 gives a view on where consumers see most of the advertisements related to mobile devices. The results are shown in percentages. The survey questions included the Internet, newspapers, billboards, television and radio as media that distribute promotional messages, advertisements. Other results include observational statements based on survey answers.

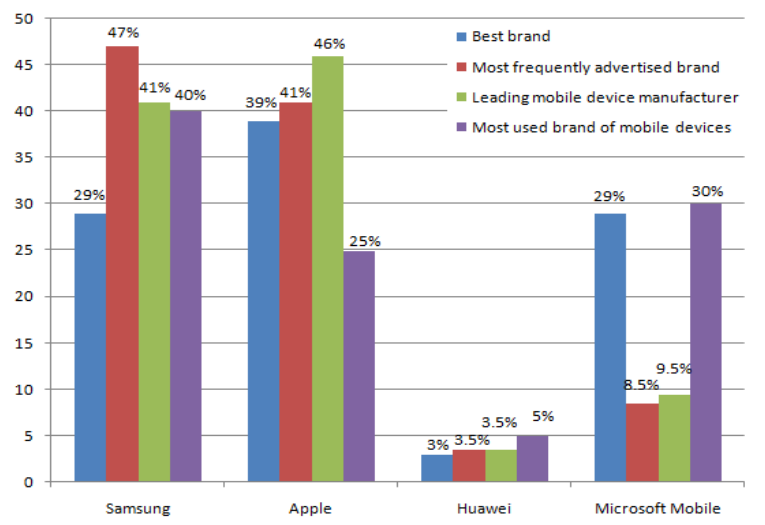

Figure 3: Consumers' opinion about best brand, advertisement, leadership on the market and most used brand on the mobile devices market (percentage) (Bakator, 2016)

Figure 3 shows the percentage of answers of mobile device users. The questions referred to opinions about best mobile device brand, most frequently advertised brand, leading mobile device 
manufacturer brand and most used brand of mobile devices.

Figure 4 shows the percentage of the answers of mobile devices users who were asked to state the brand of mobile device they would pay more, the same or less amount of money in comparison to the mobile device they currently own.

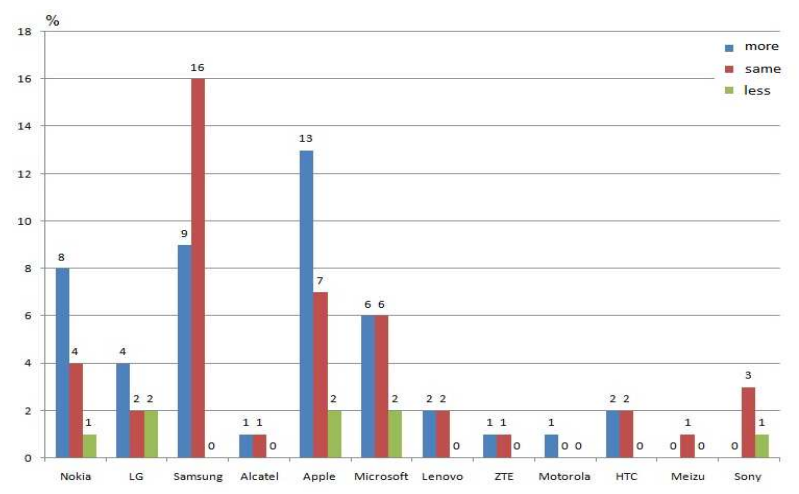

Figure 4: Consumer's opinions when asked to define how much would they pay for a new mobile device and which brand (percentage)

(Bakator, 2016)

Among the leading brands, the answers of consumers included the Motorola HTC, Meizu and Sony brand, as well as the Nokia brand excluded from Microsoft. The reason for this is to see how the top manufacturers are ranked, comparing to the not so popular ones. Interestingly, the Huawei brand wasn't mentioned at all in the questionnaire by the applicants. The possible explanation for this is that consumers, if given the chance, would rather buy the most popular brand. The next dimension of the research included the purchasing power of consumers. The applicants were asked to state their current working status and the price range of their current mobile device (Figure 5.)

Figure 5 shows that employed applicants own more expensive mobile devices, while the unemployed applicants mainly (70\%) use a mobile device in the lower price range. It can be suggested that the work status of consumers, which is connected to the purchasing power, very likely has an effect on the price of the mobile device they use.

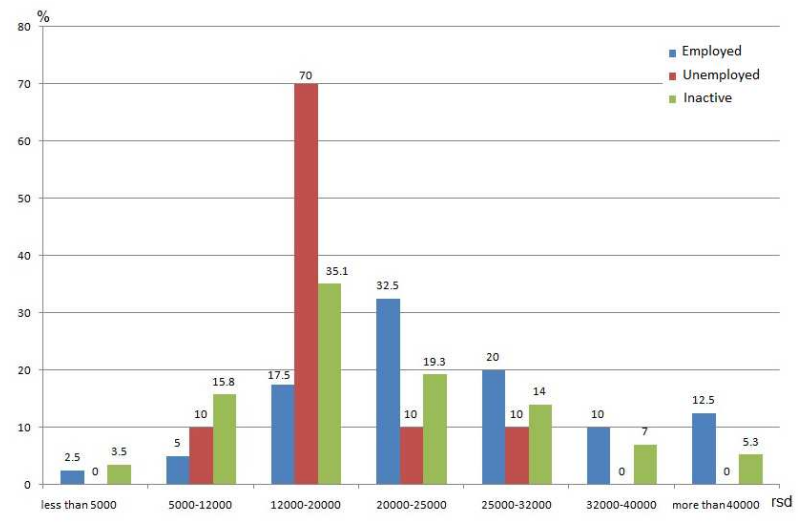

Figure 5: Price range of currently owned mobile devices sorted by work status (percentage)

(Bakator, 2016)

\section{DISCUSSION}

Observations are made based on the examination of Figures 1., 2., 3.,4., and 5., and the analysis of product quality and marketing strategy of mobile manufacturers in Serbia. Correlation between marketing strategy, product quality and promotion is best seen in customer satisfaction and customer's opinions (Turnbull et al., 2000). The research clearly showed that the popular brands and their promotional activities have respectful influence on consumer behavior. Even the low satisfaction, or to be more precise, the high dissatisfaction rates of some mobile device brands don't have problems on the market due to their active and strategic marketing communication.

Promotion has an important role in marketing communication with consumers (Teixeira, 2015). The leading mobile device manufacturers practice intensive promotional activities. While the research gives a glimpse of the true power of promotional activities, marketing strategy, and brand effect on consumers, there are some limitations in the form which do not deepen the impact of high frequency purchases of low quality products. Somewhere down the road, the brand will weaken and advertising won't have such an important role.

Strong brands have a clear advantage over weakly known brands (Khan and Ahmed, 2016). Potential mobile device users tend to buy strong brands due to its popularity and trending status. With a strong marketing strategy mobile manufacturers are more flexible on the market. The main mobile device manufacturers have strong product brands. It is more likely for these manufacturers to become leaders on a specific market segment. Product 
quality is not consistent with brand popularity. Marketing strategies in the digital age have to adapt to fast-paced changes on the market (Kotler and Keller, 2015). In this endeavor information type, place and time distribution is crucial. Business flexibility ensures that sudden changes on the market won't shift market positions of companies.

\section{CONCLUSION}

The research results tapped into the "power" of promotional activities. There is a hint of high impact of promotion on consumer behavior. Statistical analysis of data collected from the surveys show that there are traces of quality-brand compensation on the mobile devices market. The Samsung Company has a $20 \%$ dissatisfaction rate and still is the number one mobile device manufacturer. Even the negative reviews between consumers/users are not enough to destabilize the Samsung Company's market position. It is possible that aggressive promotion and high impact strategies are the reason for this effective influence. Consumers change their behavior based on influence.

The example for this is brand and quality compensation, where a strong brand compensates for the lower quality product, thus achieving low negative impact on sales frequency. Consumers show high dissatisfactory rates for the Samsung Company's mobile devices, but still buy them and perceive them as strong brand. The promotional activities create these strong brands that can withhold the negative aspects of lower quality products.

Marketing strategy of companies vary in the terms of advertising frequency, type of ads and the medium through which the advertisement is distributed. Social media sites are most popular and cost-effective distribution channels when it comes to sending a message. Therefore, the majority of marketing strategies are based on the concept of social media advertising and in a broader sense on social media marketing.

Further research is advised and the key components should include a bigger sample for surveying, at least a thousand applicants, and collecting information from mobile device service shops. With this approach the results would achieve better understanding of the complexity of influencing consumer behavior through promotional activities.

\section{REFERENCES}

Alavuk, Đ., Jevtić, J., \& Petrevska, I. (2015). Sales promotion as a determining factor in the competitive position of the company. Journal of Engineering Management and Competitiveness (JEMC), 5(1), 5054.

Ashley, C., \& Tuten, T. (2015). Creative strategies in social media marketing: An exploratory study of branded social content and consumer engagement. Psychology \& Marketing, 32(1), 15-27.

Bakator, M. (2016). Correlational relationship between marketing strategies of companies, product quality, and purchasing power of consumers in the mobile devices market. (Master thesis). Zrenjanin: University of Novi Sad, Technical Faculty "Mihajlo Pupin", Zrenjanin.

Berens, G., Riel, C. B. V., \& Bruggen, G. H. V. (2005). Corporate associations and consumer product responses: The moderating role of corporate brand dominance. Journal of Marketing, 69(3), 35-48.

Đorđević, D., Ćoćkalo, D. (2010). Osnove marketinga. Zrenjanin: University of Novi Sad, Technical Faculty Mihajlo Pupin

Fjeldstad, Ø. D., Becerra, M., \& Narayanan, S. (2004). Strategic action in network industries: an empirical analysis of the European mobile phone industry. Scandinavian Journal of Management, 20(1), 173196.

Huang, Y., Varsier, N., Niksic, S., Kocan, E., Pejanovic-Djurisic, M., Popovic, M., ... \& Person, C. (2016). Comparison of average global exposure of population induced by a macro $3 \mathrm{G}$ network in different geographical areas in France and Serbia. Bioelectromagnetics, 37(6), 382-390.

Johnston, M. W., \& Marshall, G. W. (2016). Sales force management: Leadership, innovation, technology. Routledge.

Keller, K. L. (2001). Building customer-based brand equity: A blueprint for creating strong brands Working paper series: Marketing science institute.

Keller, K.L., Aperia T., Georgson M. (2008). Strategic Brand Management- A European perspective. Harlow, England: Pearson Education Limited.

Khan, L. M., \& Ahmed, R. (2016). A comparative study of consumer perception of product quality: Chinese versus non-Chinese products. Pakistan Journal of Engineering, Technology \& Science, 2(2).

Kotler, P., Armstrong, G., Cunningham, P.,H. (2005). Principles of Marketing. Toronto: Pearson Education Canada.

Kotler, P., Keller, K. L., (2015). Marketing Management, 15th ed. Essex, England: Pearson Education Limited.

Li Sun, S. (2009). Internationalization strategy of MNEs from emerging economies: The case of Huawei. Multinational Business Review, 17(2), 129-156. 
Page, T. (2015). An Approach to the Management of the Sustainable Issues in Mobile Phone Design and Manufacturing. i-manager's Journal on Management, 10(2).

Parker, O. N., Krause, R., \& Covin, J. G. (2015). Ready, Set, Slow: How Aspiration-Relative Product Quality Impacts the Rate of New Product Introduction. Journal of Management. doi: $10.1177 / 0149206315569314$

Schlegelmilch, B. B. (2016). The Future of Global Marketing Strategy. In Global Marketing Strategy (pp. 221-249). Springer International Publishing.

Schulze, C., Schöler, L., \& Skiera, B. (2015). Customizing social media marketing. MIT Sloan Management Review, 56(2), 8.

Shankar, V., \& Balasubramanian, S. (2009). Mobile marketing: a synthesis and prognosis. Journal of Interactive Marketing, 23(2), 118-129.

Shareef, M. A., Dwivedi, Y. K., \& Kumar, V. (2016). Mobile Marketing Channel. In Mobile Marketing
Channel (pp. 25-45). Springer International Publishing.

Teixeira, D. F. P. (2015). Microsoft-Nokia: stategy and valuation. (Doctoral dissertation). Instituto Superior de Economia e Gestão.

Turnbull, P. W., Leek, S., \& Ying, G. (2000). Customer confusion: The mobile phone market. Journal of Marketing Management, 16(1-3), 143-163.

Truong, Y., Klink, R. R., Simmons, G., Grinstein, A., \& Palmer, M. (2016). Branding strategies for hightechnology products: The effects of consumer and product innovativeness. Journal of Business Research, 70, 85-91.

Yoon, T., \& Kim, K. (2015). Manufacturing of Smartphone Based Real-time Cell Observation Microscope. In Conference on Lasers and ElectroOptics/Pacific Rim (p. 27I2_6). Optical Society of America.

\section{KORELACIJA IZMEĐU MARKETING STRATEGIJE, KVALITETA PROIZVODA I PROMOCIJE NA TRŽIŠTU MOBILNIH UREĐAJA U SRBIJI}

Rad istražuje korelaciju između promocije kao instrument marketing miksa, kvaliteta proizvoda i marketing strategije na tržištu mobilnih uređaja. Rad se sastoji od četiri dela. Svaki deo definiše ključne faktore elemenata ovog rada. Istraživanje obuhvata analizu uticaja promocionih aktivnosti na ponašanje potrošača. Istraživanje je sprovedeno putem upitnika. Pitanja sa upitnika odnosila su se na marke mobilnih uređaja, zadovoljstvo korisnika mobilnih uređaja i drugih parametara kao što su pol, starost, kupovna moć i drugi. Cilj je bio određivanje uticaja promocionih aktivnosti na odluke potrošača prilikom kupovine mobilnih uređaja. Uzeti su u obzir i marke vodećih proizvođača mobilnih uređaja i marketing strategije istih. Iznete su činjenice bazirane na observaciji statsitički obrađenih podataka sa upitnika.

Ključne reči: korelacija, promocija, kvalitet proizvoda, marketing strategija, mobilni uređaj 